Historic, Archive Document

Do not assume content reflects current scientific knowledge, policies, or practices. 



\section{Semi-Annual Trade List}

\section{SPRING OF 1916}

\section{NUMBER ONE}

\section{The Farmers Nursery Co.}

\section{TROY, OHIO}

LONG DISTANCE TELEPHONE IN THE OFFICE

TELEPHONE No. 69

Grounds and Office at Southwest Corporation Line. 


\section{PLEASE READ CAREFULLY}

To those not acquainted with our establishment we would say that our nursery was established over fifty years ago (1864), incorporated in 1890 under the laws of the state of Ohio. We handle a complete assortment of Fruit and Ornamental Trees, Shrubs, Vines, Roses, etc. We have large and well equipped storage cellars and packing houses, giving us unsurpassed facilities for the prompt filling of orders.

SHIPPING FACILITIES.-We are located on the Big Four Railway, running East and West. The C. H. \& D. passes within a mile of our place which gives us an outlet North and South. Also the Dayton and Troy Traction and the Springfield, Troy and Piqua Traction pass through our city giving us hourly service between Piqua, Dayton and Springfield, and to those who are located on an electric line, with freight service, we can ship by freight over these lines, transferring at Dayton, Piqua and Springfield. The D. \& T. has through service to Toledo, Ohio.

EXPRESS COMPANIES.-Two Express Companies, the American and Wells Fargo give us excellent service.

\section{TERMS OF SALE}

PRICES.-Prices given herein are for spring 1916, and supersede all previous lists and are subject to change without further notice. The articles in this list will be furnished 5 at 10 rates; 25 at 100 rates; 250 at 1000 rates. In no case will long lists or selected varieties be supplied less than 5 of a kind of either fruit or ornamental trees or plants, etc., at lowest rates. We will not book orders made up entirely of scarce varieties.

CAUTION.-We accept all orders on condition that they shall be void should injury befall stock from frost, fire, hailstorms or other causes over which we have no control.

GRADES.-We grade carefully to a uniform standard. When both are specified, caliper measure governs, but we are careful to see that stock is uniform throughout. Our rule is "When in doubt, put in the lower grade."

CLAIMS.-All claims for errors at.d deductions must be made within six days after receipt of goods.

PACKING.-Prices contained herein are net, boxing and baling additional, for which we make charges to cover only the actual cost. Boxing and packing charged as follows.

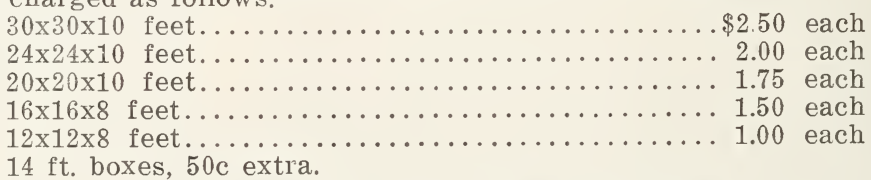

TERMS.- The usual terms to those of established credit. Cash or satisfactory reference required of unknown parties, before shipment of goods.

SHIPPING.-When ordering, please state how you wish goods shipped, whether by freight or express, also route. When no instructions are given, we forward to the best of our judgment, but in no case will we assume responsibility after shipment is delivered in good order to the railway company. Remedy for loss must lie between the buyer and the railway company, but we will gladly render all the aid we can.

GUARANTEE.-Great care is exercised to have all trees, etc., true to name and we hold ourselves ready, upon proper proof, to replace all trees, etc., that may prove untrue to name, or refund the amount paid. But it is understood between the purchaser and ourselves that this guarantee shall in no case make us liable for a sum greater than the original price paid for the trees, etc., which prove untrue to name.

REFERENCES.-For those who do not know us we refer to any bank or business house in Troy, the Commercial Agencies and the leading nurserymen of the United States. 


\section{FRUIT DEPARTMENT}

\section{APPLES AND CRABS \\ Two Year, Buds}

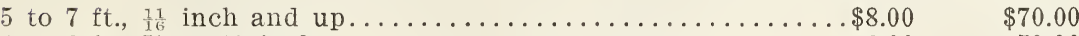

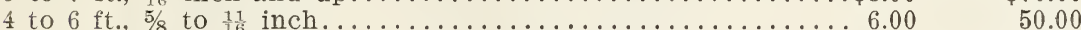

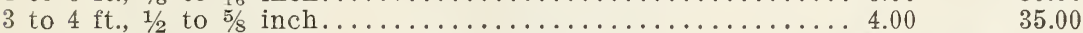

Arkansas Black

Alexander

Autumn Strawberry

Baldwin

Ben Davis

Bellflower

Chenango

Delaware Red

Delicious

Duchess

Early Harvest

Early Strawberry

Fall Pippin

Fameuse

Gano

Golden Russett

Golden Sweet

Gravenstein

Grimes Golden -

Greenville

Hubbardston

Jonathan

King

Maiden Blush

M. B. Twig

North. Spy

Northwestern Greening

Pewaukee

Rambo

Rome Beauty

Rox Russett.
Smith Cider

Spitzenberg

Staymants Winesap

Sweet Bough

Sops of Wine

Tolman

Tulpenhocken $=$

Vandevere

Wagner

Wealthy

Winesap

Winter Banana

Wolf River

Yellow Transparent

York Imperial

\section{STANDARD PEAR, 2 AND 3 YEAR}

Per 100 Per 1000

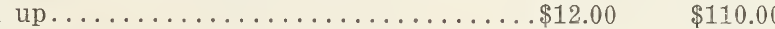

4 to $6 \mathrm{ft} ., 5 / 8$ to $3 / 4$ inch............................. $9.00 \quad 80.00$

3 to $4 \mathrm{ft} ., 1 / 2$ to $5 / 8$ inch...................................... 600

Bartlett

B.-D:-Anjou

Columbia

Duchesse-

Cl
Flemish Beauty

Garber

Koonce

Lawrence

KIEFFER PEAR, 2 YEAR

Per 100 Per 1000

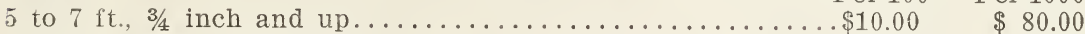

4 to $6 \mathrm{ft}$., $5 / 8$ to $3 / 4$ inch............................. $7.00 \quad 60.00$

3 to $4 \mathrm{ft} ., 1 / 2$ to $5 / 8$ inch.................................... $5.00 \quad 40.00$

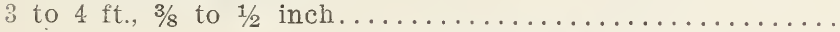

DWARF PEAR, 2 YEAR

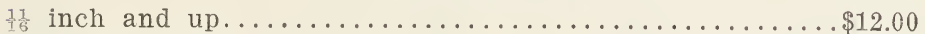

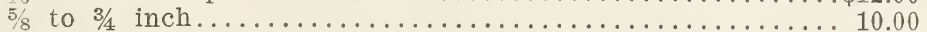

$1 / 2$ to $5 / 8$ inch................................... 7.00

CHERRY, 2 YEAR

Per 100 Per 1000

$\$ 160.00$

120.00

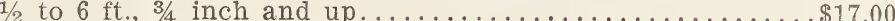

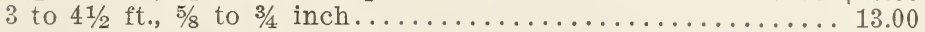

$21 / 2$ to $3 \mathrm{ft}$, $1 / 2$ to $5 / 8$ inch........................... 9.00

80.00

Sweet Cherry 5 cents extra on each grade.

Bing

Black Tartarian

Centenial

Dyehouse

Early Richmond

English Morello
Gov: Wood

Lambert

May Duke

Montmorency

Napoleon
Olivet

Oxheart

Schmidtg Biggereau

Windsor

Wragg 


\section{PLUM, 2 YEAR}

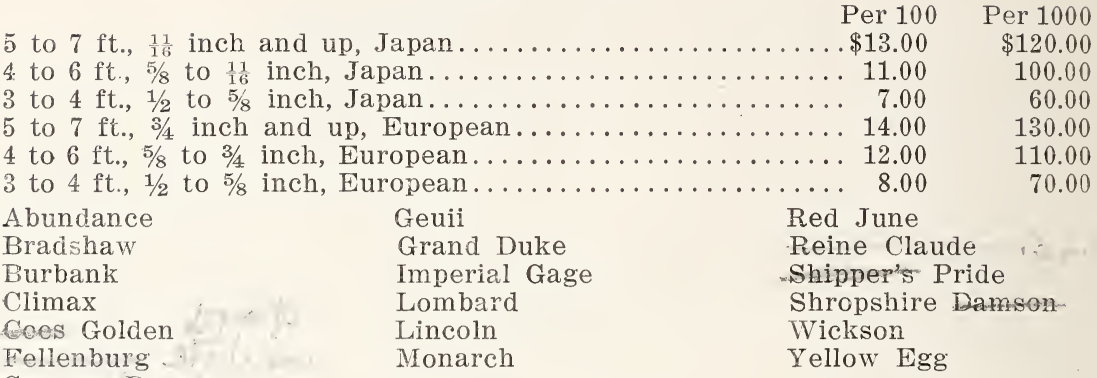

German Prune

PEACH, 1 YEAR

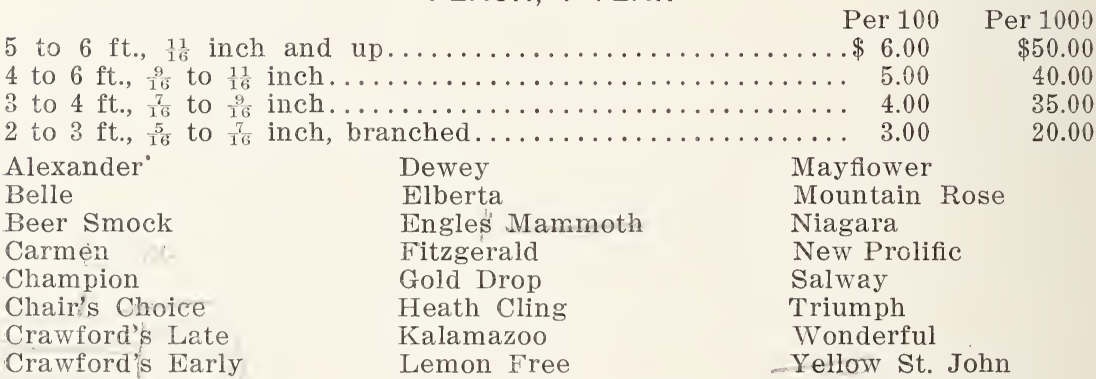

APRICOT, 1 YEAR

Per 100

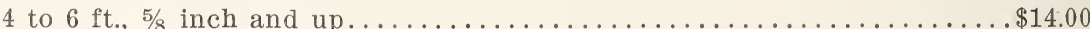

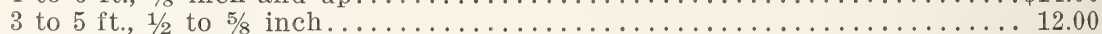

QUINCE, 2 YEAR

Per 100

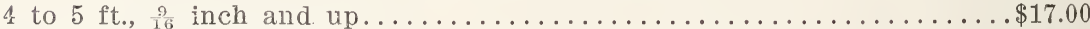

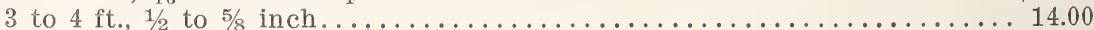

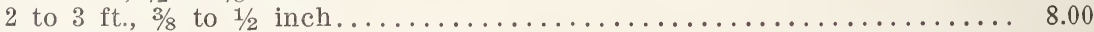

Bourgeat

Orange

Reas Mammoth

Champion

MULBERRY

Per 100

MULBERRY -Russian, 5 to 7 feet....................... $\$ 16.00$

Russian, 4 to 6 feet.......................... 14.00

Downing and New American

1 year whips, 5 to 6 feet............................. 22.00

1 year whips, 4 to 5 feet............................. 18.00

NUT TREES

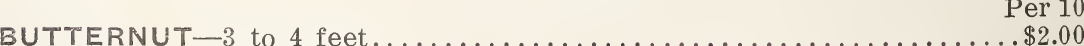

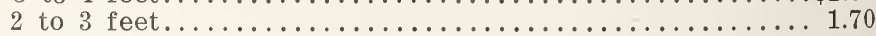

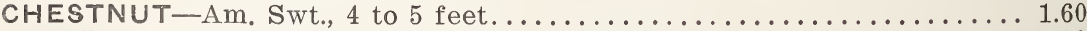

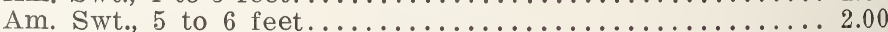

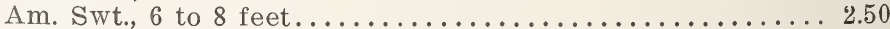

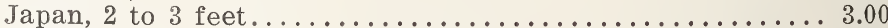

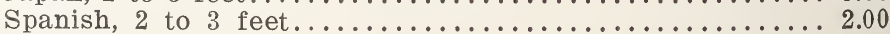




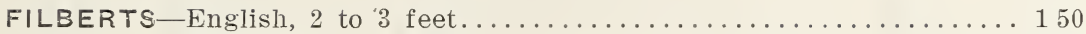

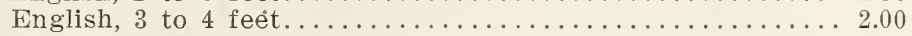

HICKORY-Shellbark, 2 to 3 feet...................... 5.00

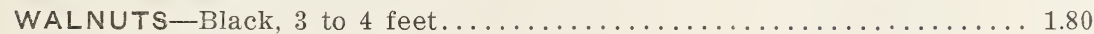

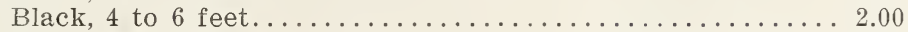

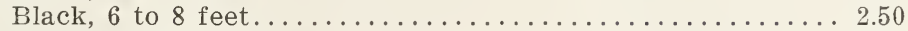

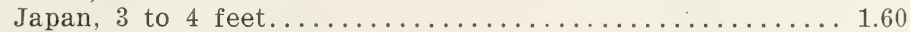

English, $11 / 2$ to 2 feet......................... 2.00

GOOSEBERRIES

Houghton, 2 year, No. 1

Per $100 \quad$ Per 1000

$\$ 4.00 \$ 35.00$

40.00

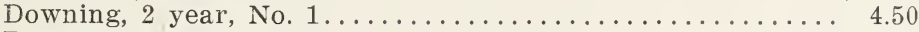

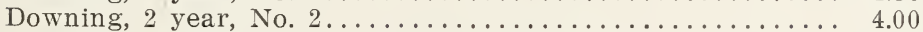

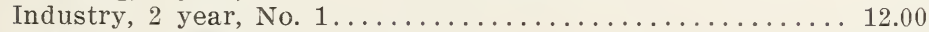

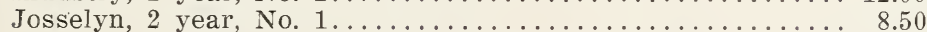

35.00

110.00

75.00

\section{CURRANTS}

Champion, black, 2 year, No. 1 .

Per 100

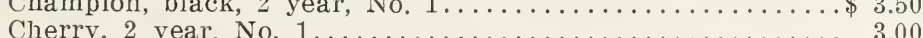

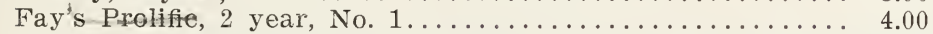

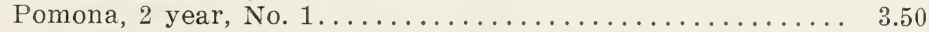

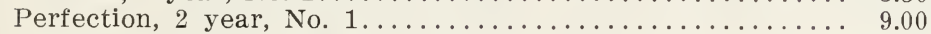

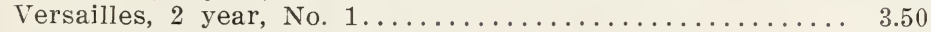

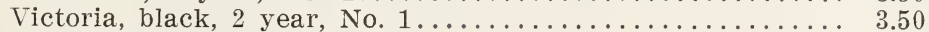

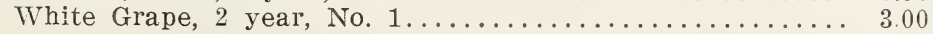

Per 1000

$\$ 30.00$

25.00

35.00

30.00

30.00

30.00

27.50

\section{GRAPE VINES}

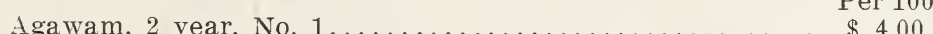

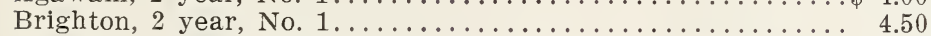

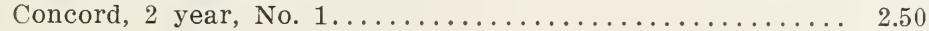

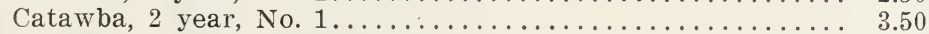

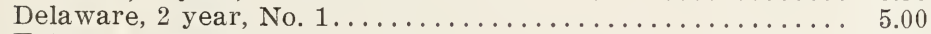

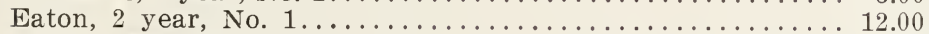

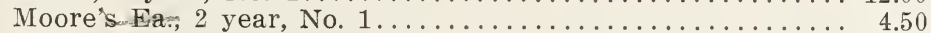

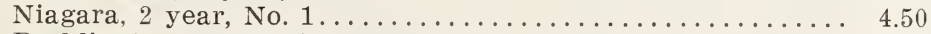

Pocklington, 2 year, No. $1 \ldots \ldots \ldots \ldots \ldots \ldots \ldots \ldots \ldots \ldots \ldots \ldots \ldots$

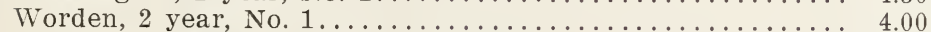

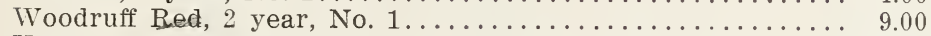

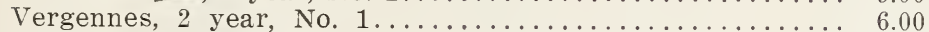

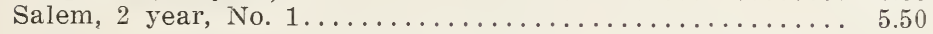

Per 1000

$\$ 35.00$

40.00

22.00

30.00

45.00

40.00

40.00

40.00

35.00

80.00

55.00

50.00

\section{RASPBERRY TIPS AND SUCKERS}

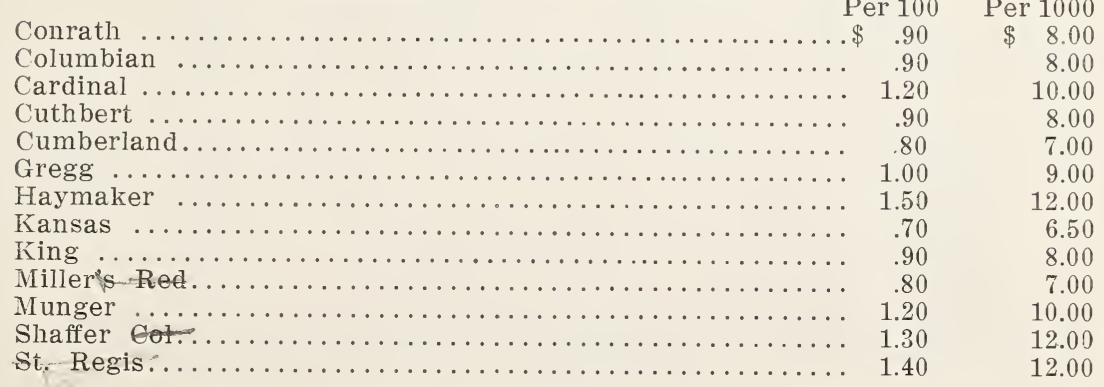




\section{BLACKBERRIES}

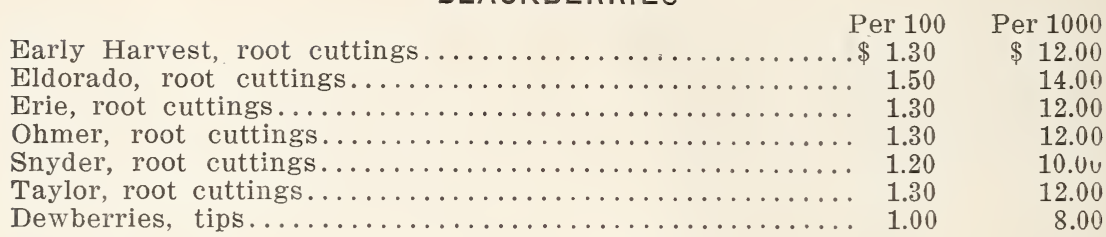

ASPARAGUS

Per 1000

Conover's Colossal, 2 years............................ $\$ 5.00$

Palmetto, 2 years..................................... 5.00

RHUBARB

Per 100

Linnaeus, 2 years................................... $\$ 1.50$

STRAWBERRIES

Glen Mary, Gandy, Nick Ohmer, Sample, Senator Dunlap, Warfield, Wm. Belt, Splendid, Tom Walker, Crescent, Hood River, Marshall....\$3.00 per 1000

\section{ORNAMENTAL DEPARTMENT}

DECIDUOUS TREES

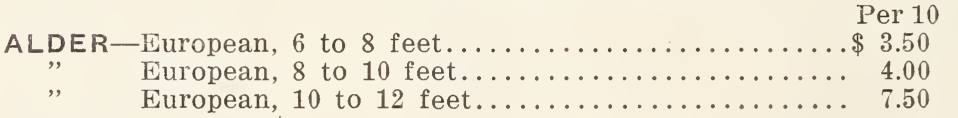

Per 100

ASH-European, 6 to 8 feet..................... 2.50

" European, 8 to 10 feet................... 3.00

" European, 10 to 12 feet..................... 3.50

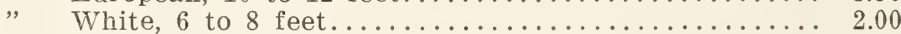

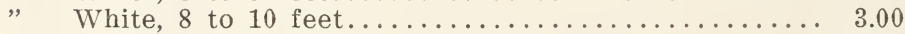

BIRCH-White American, 6 to 8 feet............... 3.00

White American, 8 to 10 feet................ 4.00

White American, 10 to 12 feet............. 5.00

CATALPA—Bungeii, 1 year head, 5 to 6 feet.......... 3.50

Bungeii, 1 year head, 6 to 8 feet......... 4.00

Bungeii, 2 year head, 5 to 6 feet.......... 6.00

Bungeii, 2 year head, 6 to 7 feet............... 6.50

Speciosa, 6 to 8 feet................. 1.80

Speciosa, 8 to 10 feet...................... 2.20

Speciosa, 10 to 12 feet.................. 3.00

12.00

18.00

CRAB APPLE-Bechtels Dbl. Fld., 3 to 4 feet.......... 3.50

Bechtels Dbl. Fld., 4 to 5 feet.......... 5.00

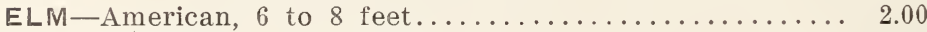

$2.00 \quad 15.00$

American, 8 to 10 feet...................... 2.50

American, 10 to 12 feet.................. 3.50

20.00

English, 6 to 8 feet....................... 4.00

English, 8 to 10 feet.................... 5.00

Scotch, 6 to 8 feet...................... 2.20

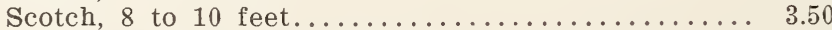

Our American Elm are budded stock from special types of heavy growing trees and extra fine. 


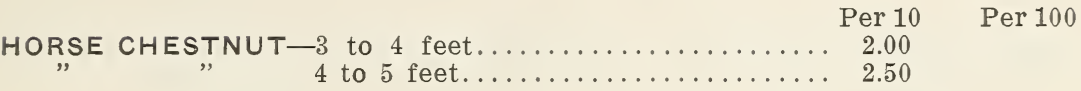

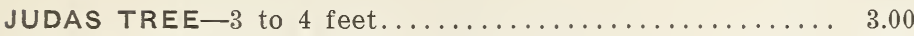

4 to 5 feet........................ 3.50

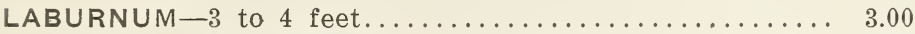

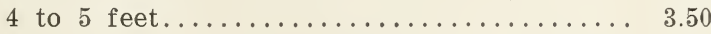

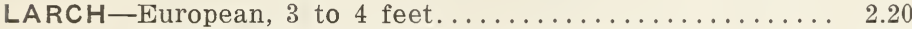

European, 4 to 6 feet........................ 300

LINDEN-American, 6 to 8 feet................ 3.50

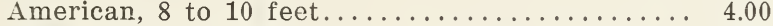

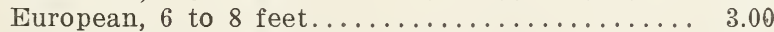

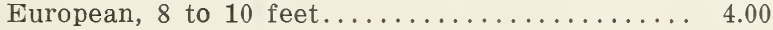

European, 10 to 12 feet............... 5.00

MAPLE-Ash, leaved, (Box Elder), 6 to 8 feet......... 1.50

Ash, leaved, (Box Elder), 8 to 10 feet........... 2.00

Ash, leaved, (Box Elder), 10 to 12 feet........ 4.00

Ash, leaved, (Box Elder), 2 inch............ 8.00

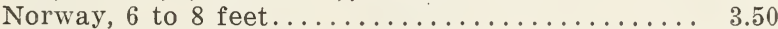

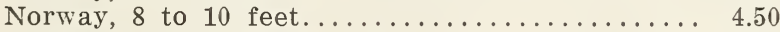

Norway, 10 to 12 feet.................. 5.50

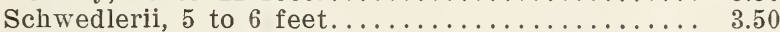

Schwedlerii, 6 to 8 feet................ 5.50

Schwedlerii, 8 to 10 feet................ 8.00

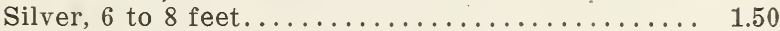

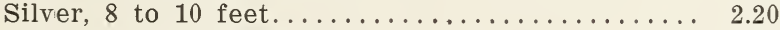

Silver, 10 to 12 feet.................. 3.50

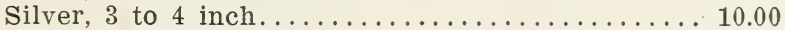

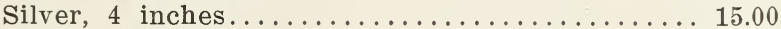

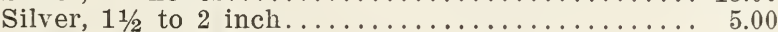

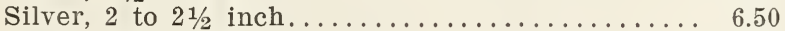

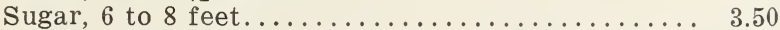

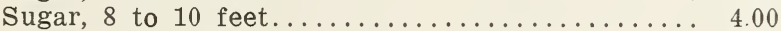

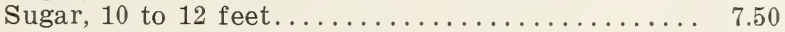

Wiers Cut Leaf, 5 to 6 feet................. 1.50

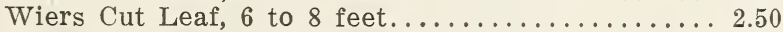

12.00

18.00

35.00

60.00

30.00

40.00

50.00

30.00

50.00

75.00

12.00

20.00

30.00

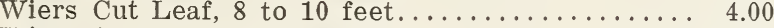

Wiers Cut Leaf, 2 to $21 / 2$ inch................ 10.00

Wiers Cut Leaf, $2 \frac{1}{2}$ to 3 inch.............. 15.00

Wiers Cut Leaf, 3 to 4 inch............... 25.00

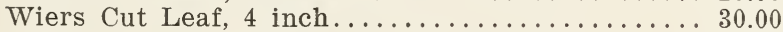

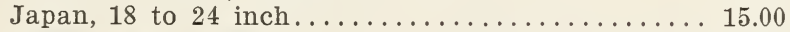

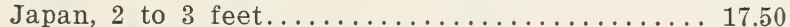

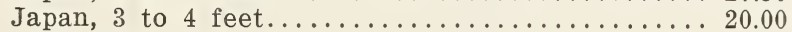

MAGNOLIA-Accuminata, 5 to 6 feet.............. 4.00 Accuminata, 6 to 8 feet.............. 5.00

MAGNOLIA DWARF-Lenne, 3 to 4 feet............. 12.50

Norberti, 3 to 4 feet........... 11.50

Alba Superba, $2 \frac{1}{2}$ to 3 feet....... 12.50

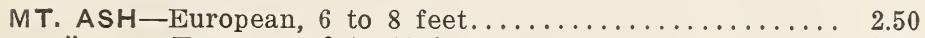
European, 8 to 10 feet................... 3.50 


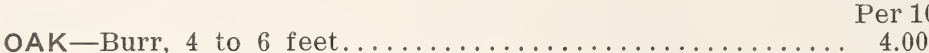

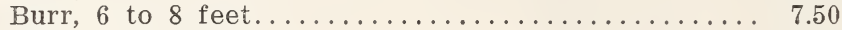

Pin, 3 to 4 feet....................... 3.00

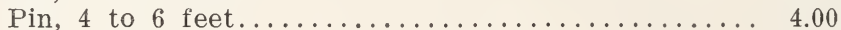

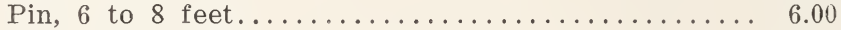

Red, 4 to 6 feet....................... 5.00

Red, 6 to 8 feet...................... 6.00

PERSIMMON-American, 3 to 4 feet............... 2.50

American, 4 to 6 feet............. 3.50

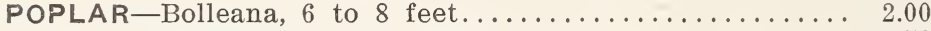

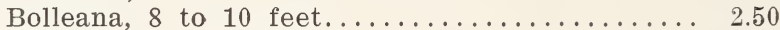

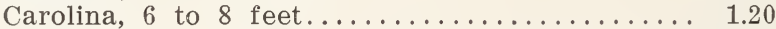

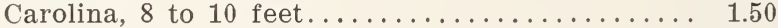

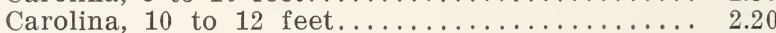

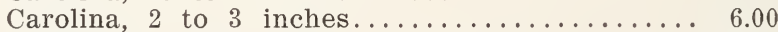

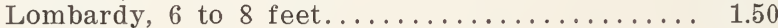

Lombardy, 8 to 10 feet................. 2.00

SYCAMORE-American, 6 to 8 feet............... 3.00

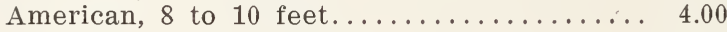

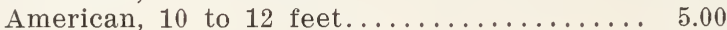

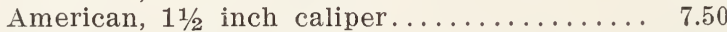

American, 2 inch caliper........... 10.00

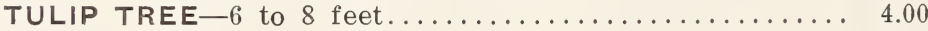

8 to 10 feet.................... 4.50

\section{WEEPING AND DECIDUOUS TREES}

BIRCH-Cut Leaf, 5 to 6 feet................... 4.50

Cut Leaf, 6 to 8 feet.................. 5.50

MULBERRY TEAS-1 year head................ 6.00

2 year head................... 8.00

ELM-Camperdown, 1 year head................ 6.00

Camperdown, 2 year head................ 7.00

WILLOW-Babylonica, 6 to 8 feet................ 2.00

Babylonica, 8 to 10 feet................ 2.50

Wisconsin, 5 to 6 feet..................... 1.20

Wisconsin, 6 to 8 feet.................. 2.00

Kilmarmock, 1 year................. 4.00

\section{DECIDUOUS SHRUBS}

AZALEA MOLLIS-12 to 15 inches................ 3.00

15 to 18 inches.................. 4.00

GHENT-18 to 24 inches................ 6.00

ALTHEAS-Named colors, dbl., 2 to 3 feet............ 80

Named colors, dbl., 3 to 4 feet............. 1.00

Variegated Leaf, 2 to 3 feet.............. 1.20

ALMONDS-Dbl. Flg., white and pink, 2 to 3 feet....... 1.20

" Dbl. Flg., white and pink, 3 to 4 feet......... 1.60

ARALIA PENTYPHYLLA-2 to 3 feet............... 1.20

3 to 4 feet............... 1.50 
Per 10

BARBERRY - Vulgaris, 15 to 18 inches.............. 40

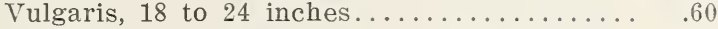

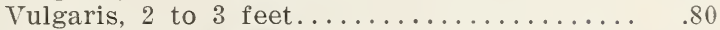

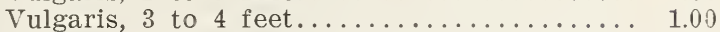

Purple Leaf, 15 to 18 inches............ .50

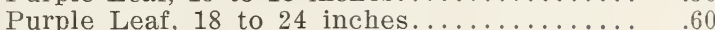

.60

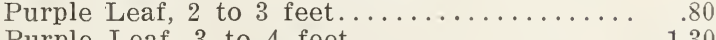

Purple Leaf, 3 to 4 feet............... 1.30

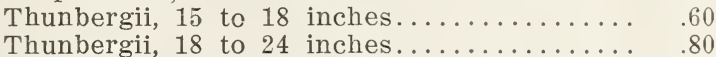

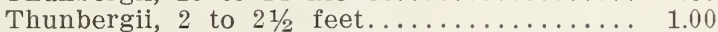

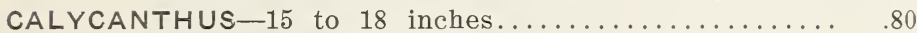

CLETHRA ALNIFOLIA -18 to 24 inches............ 1.20 2 to 3 feet..................... 1.60

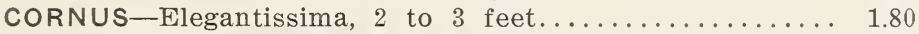

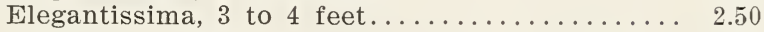

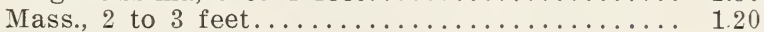

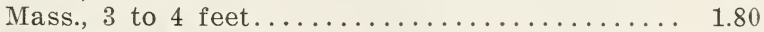

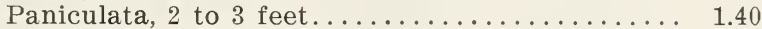

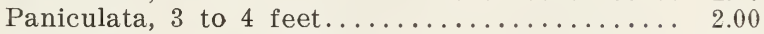

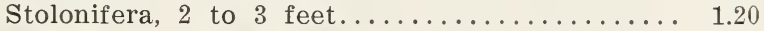

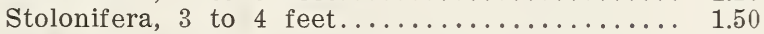

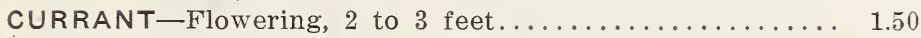

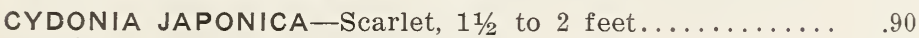

2 to 3 feet........................ 1.00

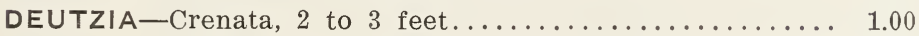

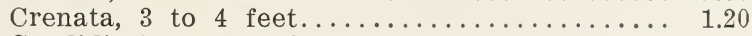

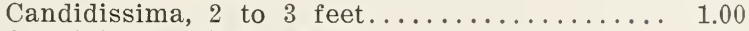

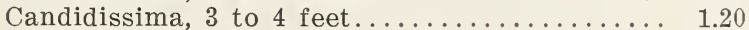

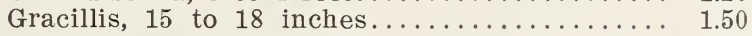

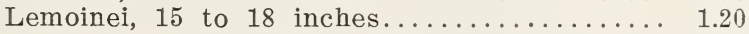

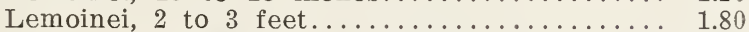

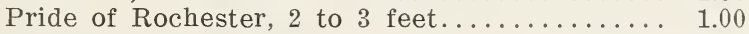

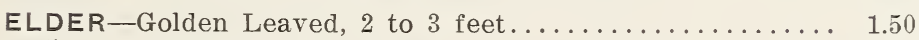

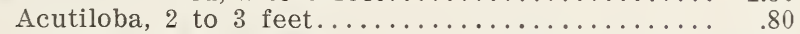

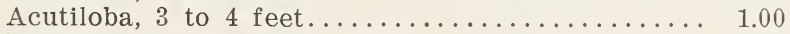

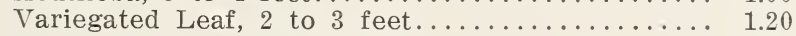

EXOCHORDA GRANDIFLORA-2 to 3 feet........... 1.20

3 to 4 feet................ 1.50

EUONYMOUS ELATUS-15 to 18 inches............. .80

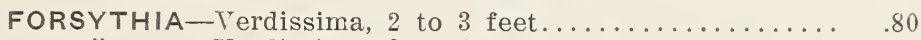

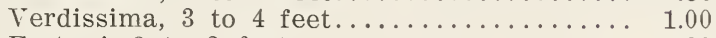

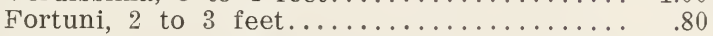

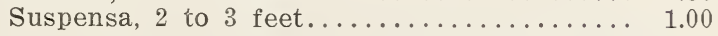

FRINGE-Purple, 2 to 3 feet................... 1.00

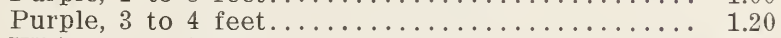

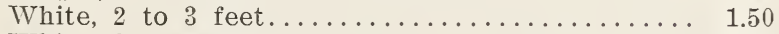

White, 3 to 4 feet....................... 1.80 
HONEYSUCKLE-Alberti, 18 to 24 inches......

Per 100

Red Tartarian, 2 to 3 feet........... 1.00

Red Tartarian, 3 to 4 feet........... 1.20

White Tartarian, 2 to 3 feet.......... 1.00

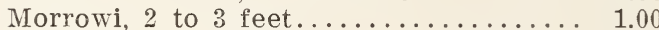

Morrowi, 3 to 4 feet.............. 1.20

HYDRANGEA-Pan. Grand, 18 to 24 inches........... . 80

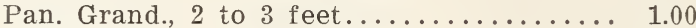

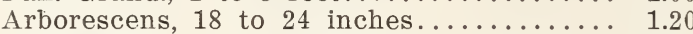

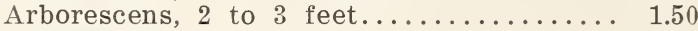

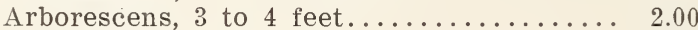

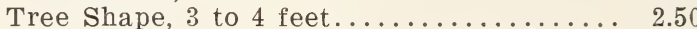

Tree Shape, 4 to 5 feet............ 3.50

KERRIA JAPONICA FL. PL. -18 to 24 inches.......... 1.20

2 to 3 feet............... 1.50

LILAC-Purple, 2 to 3 feet.................... 1.00

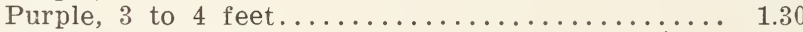

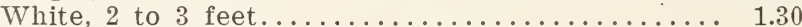

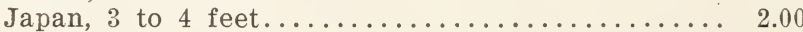

PHILADELPHUS-(Syringa or Mock Orange)

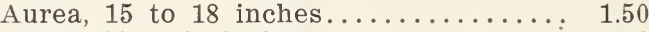

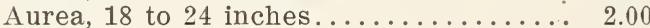

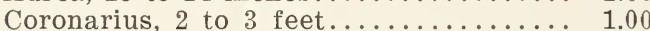

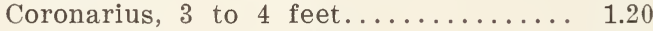

Coronarius, 4 to 6 feet............ 1.40

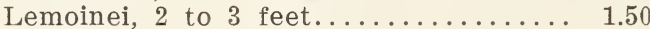

Grandiflora, 2 to 3 feet............ 1.00

Grandiflora, 3 to 4 feet........... 1.20

7.00

9.00

10.00

Per 100

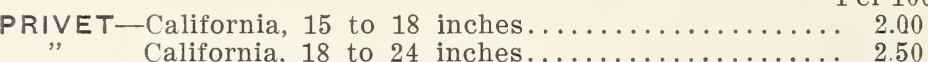

Per 1000

15.00

20.00

30.00

30.00

45.00

55.00

30.00

45.00

55.00

Amurense, 18 to 24 inches.............. 5.00

Amurense, 24 to 30 inches.............. 6.00

55.00

Per 10

PRUNUS PISSARDI -3 to 4 feet................ 1.10

Per 100

10.00

4 to 5 feet..................... 1.50

14.00

RHODODENDRONS ................................... 80

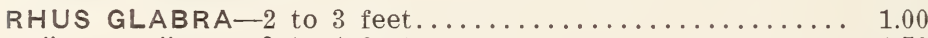

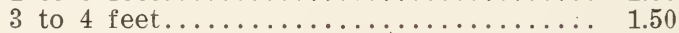

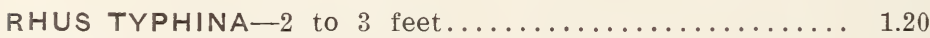

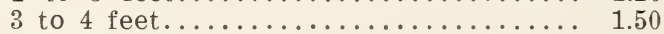

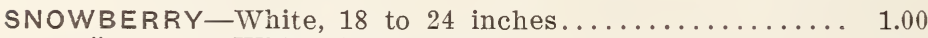

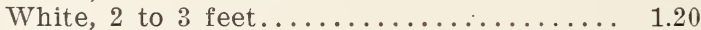

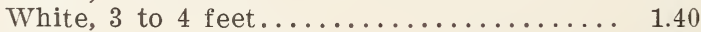

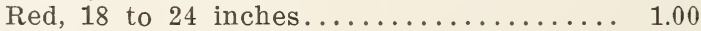

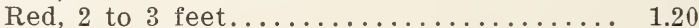

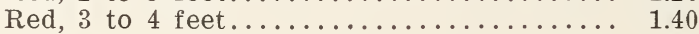

9.00

10.00

12.00

8.00

10.00

12.00 


\begin{tabular}{|c|c|c|}
\hline \multirow{2}{*}{ SPIREA-A. W., 12 to 15 inches.............. } & & Per 100 \\
\hline & 1.20 & 10.00 \\
\hline 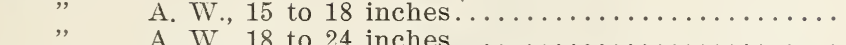 & 1.50 & \\
\hline $\begin{array}{l}\text { A. W., } 18 \text { to } 24 \text { inches... } \\
\text { Bumaldi, } 15 \text { to } 18 \text { inches }\end{array}$ & & 18.00 \\
\hline $\begin{array}{l}\text { Bumaldi, } 15 \text { to } 18 \text { inches. } \\
\text { Bumaldi, } 18 \text { to } 24 \text { inches. }\end{array}$ & 1.20 & \\
\hline $\begin{array}{l}\text { Bumaldi, } 18 \text { to } 24 \text { inches. } \\
\text { Billardii, } 3 \text { to } 4 \text { feet..... }\end{array}$ & 1 & \\
\hline $\begin{array}{l}\text { Billardii, } 3 \text { to } 4 \text { feet....... } \\
\text { Billardii, } 2 \text { to } 3 \text { feet.... }\end{array}$ & & 6.00 \\
\hline 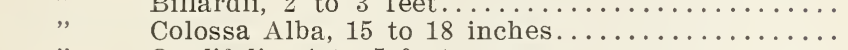 & & 5.00 \\
\hline 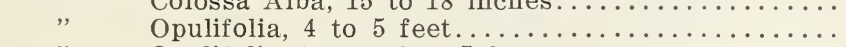 & & 10 \\
\hline 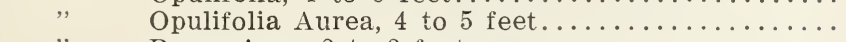 & 1.20 & \\
\hline 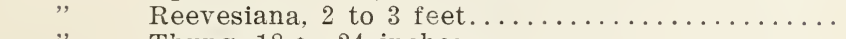 & & \\
\hline$\ldots \ldots \ldots \ldots \ldots \ldots \ldots$ & 1.00 & \\
\hline Van Houttei, 18 to & & 4.00 \\
\hline Van Houttei, 2 to 3 & & \\
\hline , 3 to 4 & & \\
\hline Van Houttei, 4 to 5 feet. & 1.2 & \\
\hline 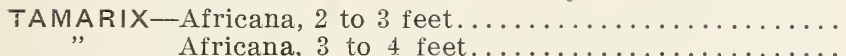 & .7 & \\
\hline 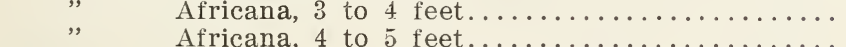 & & \\
\hline 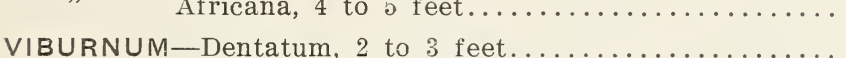 & & .00 \\
\hline 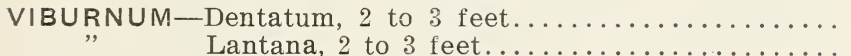 & \\
\hline 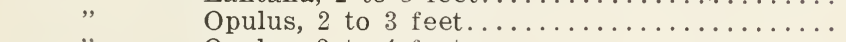 & & $\begin{array}{l}1.50 \\
1.30 \\
1.20\end{array}$ \\
\hline Opulus, 3 to 4 & & \multirow[t]{4}{*}{16.00} \\
\hline Plicatum, 2 to 3 & 1.5 & \\
\hline$\ldots \ldots \ldots \ldots \ldots \ldots+\cdots$, & 1.0 & \\
\hline$\cdots \ldots \ldots \ldots \ldots \ldots \ldots$ & 1. & \\
\hline \multicolumn{3}{|l|}{ 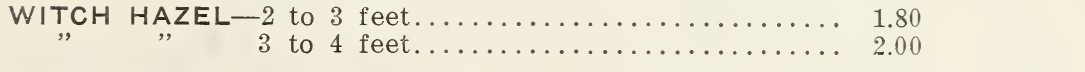 } \\
\hline \multirow{4}{*}{\multicolumn{3}{|c|}{ 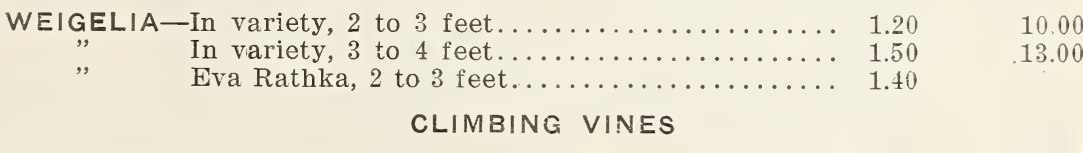 }} \\
\hline & & \\
\hline & & \\
\hline & & \\
\hline 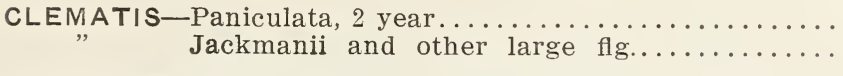 & 1.0 & \\
\hline \multirow{3}{*}{ 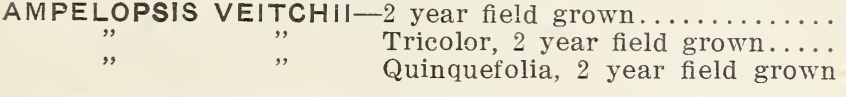 } & & \multirow{3}{*}{6.00} \\
\hline & .8 & \\
\hline & 1.0 & \\
\hline \multicolumn{3}{|l|}{ ARISTOLOCHIA SIPHO........................... 250} \\
\hline CELASTRUS SCANDENS -2 year $\ldots \ldots \ldots \ldots \ldots \ldots \ldots$ & .70 & \multirow[t]{2}{*}{6.00} \\
\hline 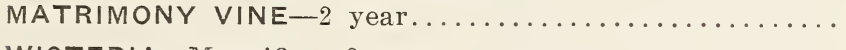 & 1.00 & \\
\hline 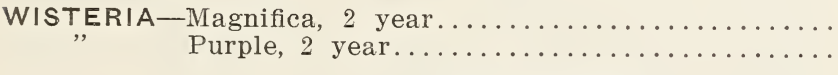 & $\begin{array}{l}1.40 \\
1.20\end{array}$ & \\
\hline & & \\
\hline
\end{tabular}

If evergreens are balled and burlapped add 8 cents to each for $1 \frac{1}{2}$ to $2 \mathrm{ft}$., 10 cents for 2 to $3 \mathrm{ft}$., 12 cents for 3 to $4 \mathrm{ft}$., and 15 cents for 4 to $5 \mathrm{ft}$. Larger sizes in proportion.

\section{Transplanted-Nursery Grown}

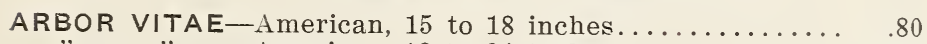
American, 18 to 24 inches.............. 1.20

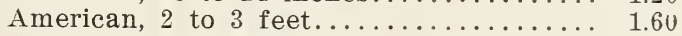
American, 3 to 4 feet................. 250 


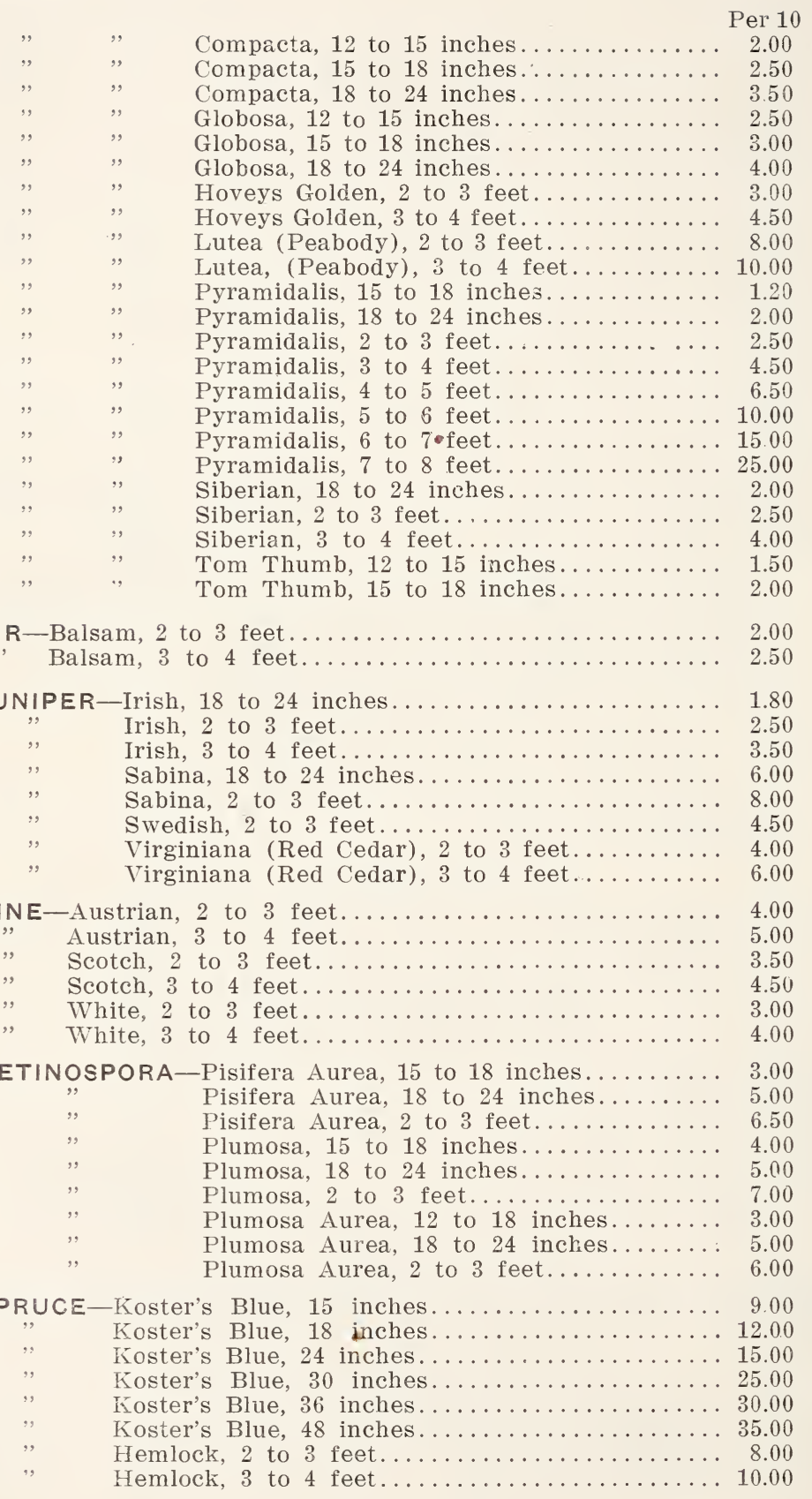

Compacta, 12 to 15 inches............. 2.00

Hoveys Golden, 2 to 3 feet............ 3.00

Hoveys Golden, 3 to 4 feet............ 4.50

Lutea (Peabody), 2 to 3 feet............ 8.00

Pyramidalis, 2 to 3 feet............. 2.50

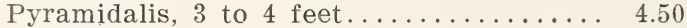

Pyramidalis, 4 to 5 feet............ 6.50

Pyramidalis, 5 to 6 feet............ 10.00

Pyramidalis, 6 to 7 feet............ 15.00

Pyramidalis, 7 to 8 feet............ 25.00

Siberian, 18 to 24 inches............ 2.00

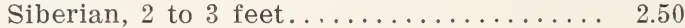

Siberian, 3 to 4 feet.............. 4.00

Tom Thumb, 12 to 15 inches.......... 1.50

Tom Thumb, 15 to 18 inches......... 2.00

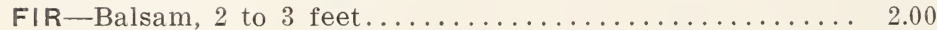

Balsam, 3 to 4 feet..................... 2.50

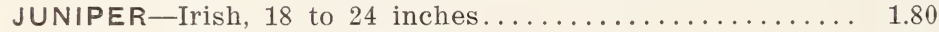

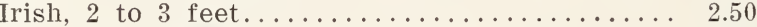

Swedish, 2 to 3 feet................... 450

Virginiana (Red Cedar), 2 to 3 feet......... 4.00

6.00

PINE-Austrian, 2 to 3 feet................... 4.00

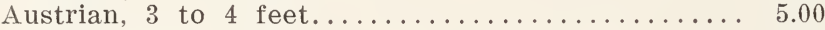

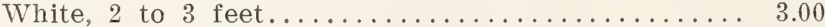

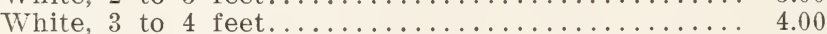

RETINOSPORA-Pisifera Aurea, 15 to 18 inches......... 3.00

Pisifera Aurea, 18 to 24 inches......... 5.00

Pisifera Aurea, 2 to 3 feet............ 6.50

Plumosa, 15 to 18 inches............. 4.00

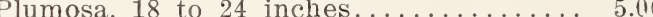


Per 100

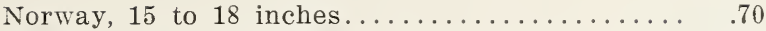

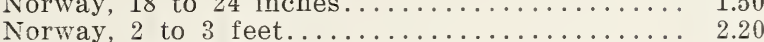

6.00

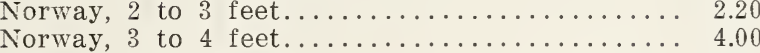

12.00

Norway, 4 to 5 feet................ 5.00

BOXWOOD-Bush Form, 15 to 18 inches............. 4.00

Bush Form, 18 to 24 inches............. 6.00

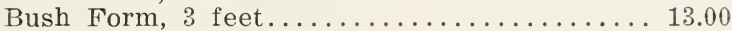

Dwarf, 4 to 6 inches............... 5.00

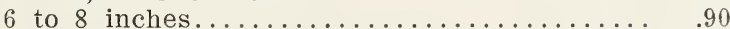

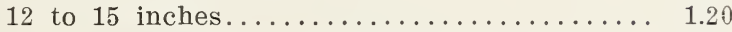

20.00

\section{ROSES-HYBRID PERPETUAL}

Hybrid Perpetual, assorted.................. 1.40

K. A. Victoria, Killarney, Mad. Car. Testout-Am. Bty., Frau Karl Druski, Maman Cochet and White Maman Cochet

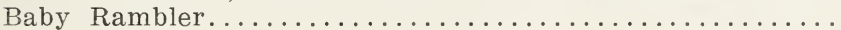
Climbing Baltimore Belle, Emp. China, Prairie Queen, Seven

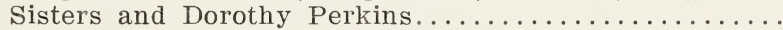

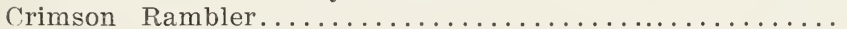

Philadelphia Rambler....................... 1.40

Yellow, Pink and White Rambler................. 1.00

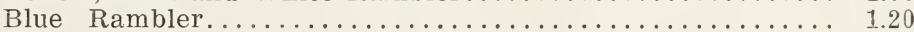

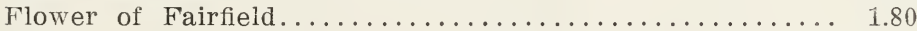

\section{SEEDLING AND TRANSPLANTING STOCK}

Per 100

Per 1000

$\$ 2.50$

3.00

4.00

24 to 36 inches.................

10.00

20.00

30.00

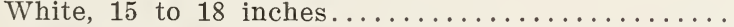

White, 18 to 24 inches

5.00

10.00

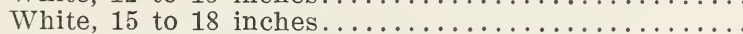

White, 18 to 24 inches

15.00

HARDY BORDER PLANTS

CHUSA ITALICA.

AQUILEGIA-Mixed $\ldots \ldots \ldots \ldots \ldots \ldots \ldots \ldots \ldots \ldots \ldots \ldots \ldots \ldots$

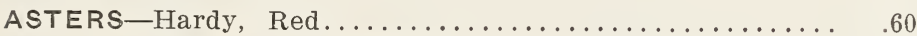

ACHILlEA TUBEROSA...................... 70

BOLTONIA LATISQUAMA.................... .60

CERASTIUM BIERBEISTEIMII................... .80

CAMPANULA GLOMERATA.................. 70 


\begin{tabular}{|c|c|c|}
\hline & Per 10 & Per 100 \\
\hline EULALIA-Glaucas & .40 & 3.00 \\
\hline 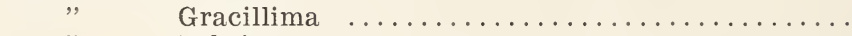 & .40 & 3.00 \\
\hline 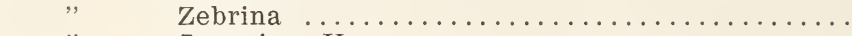 & .45 & 3.50 \\
\hline 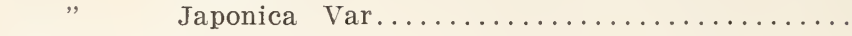 & .50 & 3.50 \\
\hline 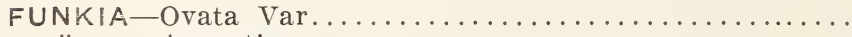 & .65 & 6.00 \\
\hline 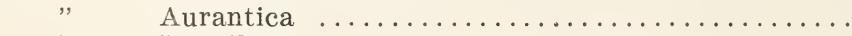 & .60 & 5.00 \\
\hline 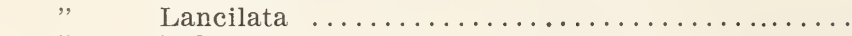 & .60 & 5.50 \\
\hline 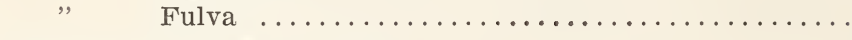 & .55 & 5.00 \\
\hline 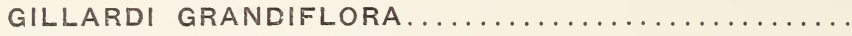 & .60 & 5.00 \\
\hline 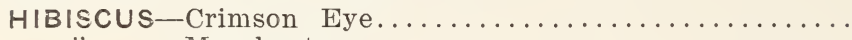 & .40 & 3.00 \\
\hline 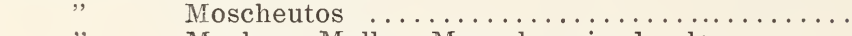 & .65 & 6.00 \\
\hline Meehans Mallow Marvels, mixed colors........ & .60 & 5.00 \\
\hline Meehans Mallow Marvels, red............ & 1.20 & 10.00 \\
\hline HOLLYHOCKS-Single, assorted, mixed colors........... & .40 & 3.00 \\
\hline HELIANTHUS-Maxima $\ldots \ldots \ldots \ldots \ldots \ldots \ldots \ldots \ldots \ldots \ldots \ldots \ldots \ldots$ & .60 & 5.00 \\
\hline 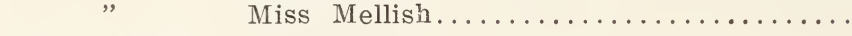 & .60 & 00 \\
\hline 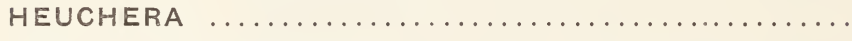 & .60 & 5.00 \\
\hline 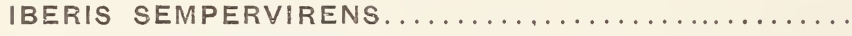 & .80 & 7.00 \\
\hline 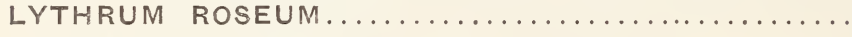 & .80 & 7.00 \\
\hline 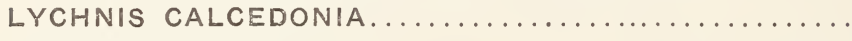 & .70 & \\
\hline ORIENTAL POPPY........... & .80 & \\
\hline 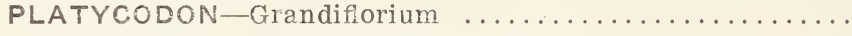 & .50 & 4.50 \\
\hline RUDEBECKIA-(Golden Glow), divisions............. & .30 & 2.50 \\
\hline 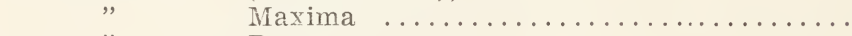 & .80 & 7.00 \\
\hline Purpurea $\ldots \ldots \ldots \ldots \ldots \ldots \ldots \ldots \ldots$ & .60 & 5.00 \\
\hline 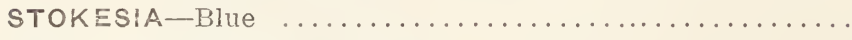 & .60 & 5.00 \\
\hline 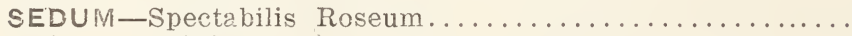 & .50 & 4.00 \\
\hline 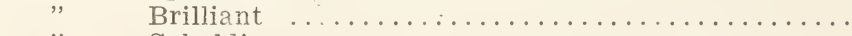 & .50 & 4.00 \\
\hline 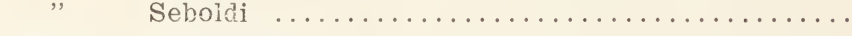 & .50 & 4.00 \\
\hline SHASTA DAISIES. & .60 & 5.00 \\
\hline TRITOMA PFITZERII......... & .80 & 7.00 \\
\hline 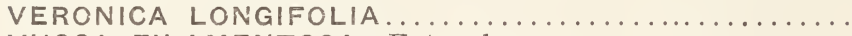 & .60 & 5.00 \\
\hline YUCCA FILAMENTOSA-Extra heavy ................ & .60 & 5.00 \\
\hline
\end{tabular}

\section{HERBACEOUS PAEONIES}

\section{3 to 5 Eyes}

Per 10 Per 100 Per 1000

Anemoneflora Rubra, Berloiz, Humeii, Queen Victoria. $\$ 1.00$ Festivia Maxima, Louis Van Houtte, Duchess De Ne-

mours, Albiflora, Meissonier.............. 2.00

Felix Crouse.......................... 2.00

Our own selection, separate colors...............80

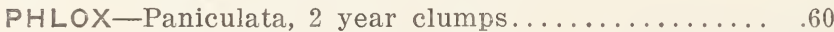

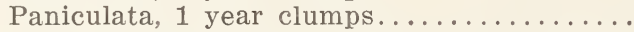

Athis, Amphitroyns, Beasnot, Blanch Nain, Brides-

maid, Champs Elysees, Coquelicot, Eclaireur, Eugene Danzanviller, Frau Anton Buchner, Heroine, Henry Munger, Jean D'Arc, L' Esprence, Pantheon, Peach Blow, R. P. Struthers, Von Lassburg, Beranger.

IRIS-German .........................

Barry, Celesta, Flavescens, Florintena Alba, Neg-

lecta, Paranesis, Purple Queen, Siberica, Gold Bound, Madam Chereau, Palladia Dalmatica.

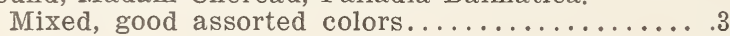




\section{ONE YEAR POTTED EVERGREENS}

Cuttings rooted in greenhouse in sand and transplanted to dirt in $21 / 2$-inch pots to develop side roots. Plants shipped with pot ball attached, each wrapped separately in paper.

\begin{tabular}{|c|c|c|c|c|}
\hline 500 & Arborvitae & Globosa, 4 to 6 inches... & $31 / 2 \mathrm{c}$ & \\
\hline 150 & $\mathrm{I}$ & Hoveyii, 8 to 10 inches. & & \\
\hline 150 & " & Hoveyii, 6 to 8 inches. & $5 \mathrm{c}$ & \\
\hline 400 & $"$ & Hoveyii, 4 to 6 inches... & $4 \mathrm{c}$ & \\
\hline 220 & " & Pumila, 6 to 8 inches. & $5 \mathrm{c}$ & \\
\hline 950 & " & Pumila, 4 to 6 inches. & $4 \mathrm{c}$ & \\
\hline 500 & " & Pyramidalis, 8 to 10 inches.. & $\mathrm{c}$ & \\
\hline & " & Pyramidalis, 6 to 8 inches..... & & \\
\hline & $"$ & Pyramidalis, 4 to 6 inches. & $31 / 2 \mathrm{c}$ & \\
\hline & $"$ & Verveaneana, 4 to 6 inches....... & & \\
\hline & & to 10 inches & 8 & \\
\hline & & a, 8 to 10 inches. & & \\
\hline & $"$ & Plumosa Aurea, 4 to 6 inches. . & $4 \mathrm{c}$ & \\
\hline & ar & & $1 /$ & \\
\hline
\end{tabular}

\section{TWO YEAR EVERGREENS IN BEDS}

Transplanted from pots to beds outside and grown an extra year. All plants heavily mudded and securely packed in small open cases.

1000 Arborvitae American, 8 to 10 inches................. 5c each

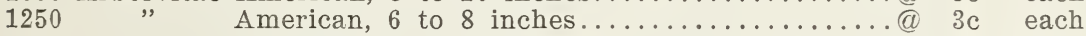

$1800 \quad "$ Compacta, 6 to 8 inches................ 5c each

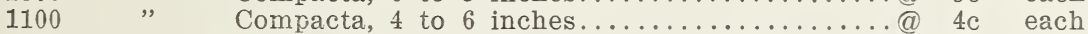

$100 \quad " \quad$ Globosa, 6 to 8 inches..................... $5 \mathrm{c}$ each

$225 \quad " \quad$ Globosa, 4 to 6 inches................... 31/2c each

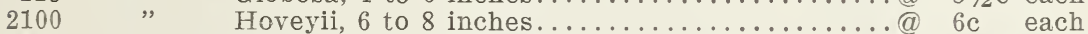

$1300 \quad " \quad H o v e y i i, 4$ to 6 inches..................@4c each

$350 \quad " \quad$ Pumila, 8 to 10 inches................. 7c each

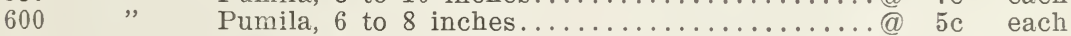

$450 \quad " \quad$ Pumila, 4 to 6 inches....................@31/2c each

$200 \quad " \quad$ Verveaneana, 6 to 8 inches..............@ 5c each

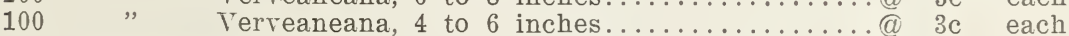

1800 Retinospora Plumosa Aurea, 6 to 8 inches.............@ 4c each

$600 \quad " \quad$ Plumosa Aurea, 4 to 6 inches................. 3c each

\section{THREE YEAR EVERGREENS IN BEDS}

Transplanted from pots to beds, grown one year and transplanted again. These have developed the finest root systems we have ever seen. Packed the same as the two year plants.

1400 Retinospora Plumosa, 6 to 8 inches............... 5c each

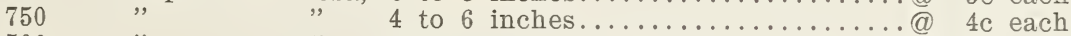

$500 \quad " \quad$ Aurea, 8 to 10 inches..............6. 6c each

$1925 \quad " \quad$ Aurea, 6 to 8 inches................ 5c each 


\section{Certificate of Inspection}

No. 40 .

Columbus, Ohio, Aug. 19, 1915.

This is to certify, that the nursery stock for sale by The Farmers Nursery Company, of Troy, County of Miami, State of Ohio, consisting of general nursery stock has been inspected by a duly authorized inspector, in compliance with Section 1124, Page 314, Laws of Ohio, 1913, and has been found apparently free from dangerously injurious insects and plant diseases.

Valid until September 15, 1916, unless revoked.

Signed, The Agricultural Commission of Ohio.

A. P. SANDLES, President.

N. E. SHAW, Chief Inspector. 